\title{
Effects of plant extracts on antioxidant status and oxidant-induced stress in Caco-2 cells
}

\author{
S. Aisling Aherne, Joseph P. Kerry and Nora M. O'Brien* \\ Department of Food and Nutritional Sciences, University College Cork, Cork, Republic of Ireland
}

(Received 28 April 2006 - Revised 18 August 2006 - Accepted 29 August 2006)

\begin{abstract}
Experimental evidence suggests that most herbs and spices possess a wide range of biological and pharmacological activities that may protect tissues against $\mathrm{O}_{2}$-induced damage. The objectives of the present study were: first, to determine the effects of plant extracts on the viability, membrane integrity, antioxidant status and DNA integrity of Caco-2 cells and second, to investigate the cytoprotective and genoprotective effects of these plant extracts against oxidative stress in Caco-2 cells. The plant extracts examined were rosemary (Rosmarinus officinalis L.), oregano (Origanum vulgare L.), sage (Salvia officinalis L.) and echinacea (Echinacea purpurea L.). Cell membrane integrity was assessed by the lactate dehydrogenase release assay. Viability was determined by the neutral red uptake assay (NRUA) and the concentration of compound that resulted in $50 \%$ cell death $\left(\mathrm{IC}_{50}\right)$ was calculated. Antioxidant status of the cells was assessed by measuring GSH content, catalase activity and superoxide dismutase activity. To examine their cytoprotective and genoprotective effects, Caco- 2 cells were pre-treated with each plant extract for $24 \mathrm{~h}$ followed by exposure to $\mathrm{H}_{2} \mathrm{O}_{2}$. DNA damage was assessed by the comet assay and cell injury was determined by the NRUA. Rosemary was the most toxic $\left(\mathrm{IC}_{50} 123 \mu \mathrm{g} / \mathrm{ml}\right)$ and echinacea the least toxic $\left(\mathrm{IC}_{50} 1421 \mu \mathrm{g} / \mathrm{ml}\right)$. Sage was the only plant extract to affect the antioxidant status of the cells by increasing GSH content. Sage, oregano and rosemary protected against $\mathrm{H}_{2} \mathrm{O}_{2}$-induced DNA damage (olive tail moment and percentage tail DNA), whereas protection against $\mathrm{H}_{2} \mathrm{O}_{2}$-induced cytotoxicity was afforded by sage only.
\end{abstract}

Herbs: Antioxidants: DNA damage: Comet assay: Caco-2 cells

Oxidative stress and reactive oxygen species-mediated cell damage have been implicated in the development of various human chronic diseases such as Crohn's disease, CVD, certain cancers and a number of neurodegenerative diseases (Babbs, 1992; Halliwell \& Gutteridge, 1999; Parthasarathy et al. 1999; Sohal et al. 2002). At the cellular level, subjecting cells to oxidative stress can result in severe metabolic dysfunction, including lipid peroxidation, protein oxidation, membrane disruption and DNA damage (Halliwell \& Gutteridge, 1999).

Oxidative damage can also have undesirable effects on foods such as the production of rancid odours and flavours which can reduce the shelf-life, nutritional quality and safety of food products (Zainol et al. 2003; Chanwitheesuk et al. 2005). In order to lower the risk of oxidative deterioration, synthetic antioxidants have been added to many food products. However, due to safety issues and consumer demand, there has been considerable interest in replacing synthetic antioxidants with natural plant-based alternatives. Therefore, an increasing number of plant-derived antioxidant preparations are commercially available for use in food applications (Aruoma et al. 1996; Mielnik et al. 2003).

Over the past few decades, research has focused on the health effects of phytochemicals and plant-derived extracts. The Lamiaceae family is a large group of plant species that contain substantial amounts of phenolic compounds (Moreno et al. 2006). Popular varieties from this family include the culinary herbs: rosemary (Rosmarinus officinalis L.), oregano (Origanum vulgare L.) and sage (Salvia officinalis L.). Experimental evidence suggests that most herbs and spices, especially those of the Lamiaceae family, possess a wide range of biological and pharmacological activities that may protect tissues against $\mathrm{O}_{2}$-induced damage and therefore lower the risk of human chronic diseases (Craig, 1999; KrisEtherton et al. 2002; Bozin et al. 2006).

Natural phytochemicals present at low levels in fruit, vegetables, herbs and spices offer many health benefits, but these compounds may not be effective or safe when consumed at higher does (Liu, 2003). If herbal use is to be extended to applications that require high doses, the increased exposure to human consumers is a matter of concern (Aydin et al. 2005). The objective of the present study, therefore, was to investigate the toxicity and biological activity of rosemary, oregano, sage and echinacea extracts using a human colon carcinoma cell line, Caco-2 cells, as a model system. The paper presents the effects of rosemary, oregano, sage and echinacea extracts on the viability, membrane integrity, antioxidant status and DNA integrity of Caco-2 cells. In the present study, the four plant extracts were also investigated for their potential cytoprotective and genoprotective effects against $\mathrm{H}_{2} \mathrm{O}_{2}$-induced stress in Caco- 2 cells.

Abbreviations: GAE, gallic acid equivalent; $\mathrm{IC}_{50}$, concentration resulting in $50 \%$ cell death; LDH, lactate dehydrogenase; OTM, olive tail moment.

* Corresponding author: Professor Nora O’Brien, fax +35321 4270244, email nob@ucc.ie 


\section{Materials and methods}

\section{Materials}

All chemicals and cell culture reagents were obtained from Sigma Chemical Co. (Poole, Dorset, UK) unless otherwise stated. Rosemary (Rosmarinus officinalis), oregano (Origanum vulgare), sage (Salvia officinalis) and echinacea (Echinacea purpurea (L.), Moench-Asteraceae family) extracts were purchased from Guinness Chemicals (Portlaoise, Co. Laois, Republic of Ireland). Suppliers provided the following information based on HPLC analysis: No information was available on the oregano extract. Rosemary extract contained rosmarinic acid $(7 \%, \mathrm{w} / \mathrm{v})$. The key compounds detected in the sage extract were rosmarinic acid $(7.03 \%, \mathrm{w} / \mathrm{v})$, flavones $(3.21 \%, w / v)$ and flavanones $(5 \cdot 13 \%, w / v)$. Echinacea extract contained various caffeic acid compounds (8.35\% total, w/v).

\section{Total phenol content}

Total phenolic content of the extracts was determined by employing the methods given in the literature involving Folin-Ciocalteu reagent and gallic acid as standard (Singleton \& Rossi, 1965).

\section{Cell culture}

Human Caucasian colon adenocarcinoma Caco-2 cells were purchased from the European Collection of Animal Cell Cultures (Salisbury, Wilts, UK). Cells were cultured in an atmosphere of $\mathrm{CO}_{2}-$ air $\left(5: 95, \quad \mathrm{v} / \mathrm{v} ; \mathrm{O}_{2}\right.$ partial pressure of $19.998 \mathrm{kPa}$ ) at $37^{\circ} \mathrm{C}$. Caco-2 cells were grown in Dulbecco's modified Eagle's medium supplemented with fetal bovine serum $(10 \%, \mathrm{v} / \mathrm{v})$ and non-essential amino acids (1\%, v/v). Cells were maintained in the absence of antibiotics. For all experiments, Caco-2 cells were seeded at a density of $3 \times 10^{4}$ cells per $\mathrm{cm}^{2}$ in cell culture plates.

\section{Incubation of Caco-2 cells with plant extracts or oxidants}

After $24 \mathrm{~h}$ growth in the appropriate culture plates, growth media was replaced with growth medium containing reduced fetal bovine serum ( $5 \%, \mathrm{v} / \mathrm{v})$ and non-essential amino acids $(1 \%, \mathrm{v} / \mathrm{v})$ in the presence or absence of the herb extracts, except for the lactate dehydrogenase (LDH) release assay where $2.5 \%$ (v/v) fetal bovine serum was used. Rosemary, oregano, sage and echinacea extracts were dissolved in nonsupplemented Dulbecco's modified Eagle's medium. Control cultures were exposed to the equivalent concentration of carrier and were found not to significantly differ from cells grown in media only. $\mathrm{H}_{2} \mathrm{O}_{2}$ was dissolved in ice-cold PBS and treatments with the oxidant were in the absence of serum.

For the determination of cell viability, concentration resulting in $50 \%$ cell death $\left(\mathrm{IC}_{50}\right)$ values and cell membrane integrity, Caco- 2 cells were supplemented with increasing concentrations $(5-1000 \mu \mathrm{g} / \mathrm{ml})$ of rosemary, oregano, sage or echinacea extracts for $24 \mathrm{~h}$. For subsequent assays, the concentration of each plant extract that corresponded to greater than $90 \%$ cell viability was selected, namely: $15 \mu \mathrm{g} / \mathrm{ml}$ rosemary, $60 \mu \mathrm{g} / \mathrm{ml}$ oregano, $60 \mu \mathrm{g} / \mathrm{ml}$ sage and $250 \mu \mathrm{g} / \mathrm{ml}$ echinacea. Cell viability was also determined in Caco- 2 cells exposed to $\mathrm{H}_{2} \mathrm{O}_{2}(50 \mu \mathrm{M}$ for $30 \mathrm{~min})$ and $(100-500 \mu \mathrm{M}$ for $2 \mathrm{~h})$. To determine protection against oxidant-induced DNA damage, cells were supplemented with or without the plant extracts for $24 \mathrm{~h}$ followed by exposure to $50 \mu \mathrm{M}-\mathrm{H}_{2} \mathrm{O}_{2}$ for $30 \mathrm{~min}$ at $37^{\circ} \mathrm{C}$. To investigate protection against oxidant-induced cytotoxicity, Caco-2 cells were supplemented in the presence or absence of each plant extract for $24 \mathrm{~h}$ followed with or without exposure to $\mathrm{H}_{2} \mathrm{O}_{2}$ $(100-500 \mu \mathrm{M})$ for $2 \mathrm{~h}$ at $37^{\circ} \mathrm{C}$.

\section{Cell membrane integrity (lactate dehydrogenase release assay)}

Media was collected from all test wells of a ninety-six-well plate. LDH leakage into the growth media and total LDH (LDH leakage plus LDH inside cells) were measured using an in vitro lactate dehydrogenase release assay kit (Biogenesis, Poole, Dorset, UK). LDH release was expressed as a percentage of total $\mathrm{LDH}$.

\section{Cell viability (neutral red uptake assay)}

The neutral red uptake assay, by the method of Babich \& Borenfreund (1992), was used to assess cell viability. Neutral red dye was prepared as a $0.4 \%(\mathrm{w} / \mathrm{v})$ stock solution, which was diluted 1/100 using Dulbecco's modified Eagle's medium and pre-incubated overnight at $37^{\circ} \mathrm{C}$. After $3 \mathrm{~h}$ incubation with the dye $(40 \mu \mathrm{g} / \mathrm{ml})$ at $37^{\circ} \mathrm{C}$, cells were quickly washed with a fixative $\left(1 \% \mathrm{CaCl}_{2}, 0.5 \%\right.$ formaldehyde) and then solubilised. Absorbance was read at $540 \mathrm{~nm}$ on a microtitre plate reader. The $\mathrm{IC}_{50}$ value for each plant extract (concentration of compound that reduced cell viablity by $50 \%$ ) was calculated using the data obtained from the neutral red uptake assay and GraphPad Prism software version 4.0 (GraphPad Inc., San Diego, CA, USA).

\section{Reduced glutathione content}

GSH content was determined by the method of Hissin \& Hilf (1976). Perchloric acid (15\%, v/v) was added to the cell sonicates and samples were centrifuged at $14000 \mathrm{rpm}$ for $30 \mathrm{~min}$ at $4^{\circ} \mathrm{C}$. The final GSH assay mixture contained $100 \mu$ l sample, $1.8 \mathrm{ml}$ phosphate-EDTA buffer $(\mathrm{pH} 8)$ and $100 \mu \mathrm{l} \sigma$-phthaldialdehyde $(1 \mathrm{mg} / \mathrm{ml})$. Fluorescence was detected at $430 \mathrm{~nm}$ following excitation at $360 \mathrm{~nm}$. GSH content was expressed relative to the protein content, as determined by the bicinchoninic acid method (Smith et al. 1985).

\section{Antioxidant enzyme activity assays}

Catalase activity was determined using a modification of the method of Baudhuin et al. (1964), where any remaining $\mathrm{H}_{2} \mathrm{O}_{2}$ is determined as a yellow 'peroxy titanium sulfate'. One unit of catalase activity is defined as the amount of catalase required to decompose $1 \mu \mathrm{mol} \mathrm{H}_{2} \mathrm{O}_{2}$ per min at $\mathrm{pH} 7.5$ and $25^{\circ} \mathrm{C}$. Superoxide dismutase activity was measured by the method of McCord \& Fridovich (1969). One unit of superoxide dismutase activity is defined as the amount of superoxide dismutase required to inhibit the maximum rate of cytochrome $\mathrm{C}$ reduction by $50 \%$. Enzyme activities were expressed as units of enzyme activity per mg protein (Smith et al. 1985).

\section{Alkaline single cell gel electrophoresis (comet) assay}

DNA damage was assessed using the comet assay by the method of Tice et al. (1990). Briefly, treated and non-treated 
cells were gently scraped and embedded in low-melting-point agarose on coded microscope slides. Samples were then placed in cold lysis solution $(2.5 \mathrm{M}-\mathrm{NaCl}, 100 \mathrm{mM}$-EDTA, $10 \mathrm{~mm}$-tri(hydroxymethyl)-aminomethane, $1 \%$ sodium sarcosinate $(\mathrm{pH} 10)$, with fresh $1 \%$ Triton ${ }^{\circledR} \mathrm{X}-100$ and $10 \%$ dimethyl sulfoxide) for $1.5 \mathrm{~h}$ at $4^{\circ} \mathrm{C}$. Slides were aligned in a horizontal gel electrophoresis tank (Horizon ${ }^{\circledR}$ 20.25; GIBCO BRL Life Technologies, Gaithersburg, MD, USA) which was filled with fresh electrophoresis solution (1 mM-EDTA, $300 \mathrm{~mm}-\mathrm{NaOH} ; \mathrm{pH}$ 13). Slides were allowed to sit in this buffer for $30 \mathrm{~min}$. Electrophoresis was conducted at $1 \mathrm{~V} / \mathrm{cm}$ for $25 \mathrm{~min}$ at $4^{\circ} \mathrm{C}$. After electrophoresis, the slides were washed three times with neutralising buffer and stained with ethidium bromide $(20 \mu \mathrm{g} / \mathrm{ml})$. Fifty nuclei per slide were analysed using computer-assisted image analysis (Komet 4; Kinetic Imaging, Liverpool, UK). The extent of DNA damage was expressed in two ways: (i) the mean percentage of tail DNA, reflecting the proportion of DNA that has migrated from the head and (ii) olive tail moment (OTM), which represents the product of the tail length and the percentage DNA in the tail.

\section{Statistical analysis}

Results are presented as mean values with their standard errors. Data were analysed by one-way ANOVA followed by Dunnett's test. The level of statistical significance was taken at $P<0.05$ or $P<0.01$.

\section{Results}

Total phenolic content of plant extracts

The total phenolic content of the four plant extracts was as follows: rosemary, $207 \mathrm{mg}$ gallic acid equivalents (GAE)/g; sage, $192 \mathrm{mg} \mathrm{GAE} / \mathrm{g}$; oregano, $78 \mathrm{mg}$ GAE/g; echinacea, $58 \mathrm{mg} \mathrm{GAE} / \mathrm{g}$.
Effects of plant extracts on the membrane integrity of Caco-2 cells

Caco-2 cells were grown in the presence or absence of rosemary, oregano, sage or echinacea $(5-1000 \mu \mathrm{g} / \mathrm{ml})$ for a period of $24 \mathrm{~h}$. Following incubation, cell membrane integrity was determined using the $\mathrm{LDH}$ release assay. At concentrations $\geq 120 \mu \mathrm{g} / \mathrm{ml}$, rosemary and sage significantly increased LDH leakage from the cells (Fig. 1). Supplementation of Caco- 2 cells with oregano $(\geq 500 \mu \mathrm{g} / \mathrm{ml})$ or echinacea $(1000 \mu \mathrm{g} / \mathrm{ml})$ significantly induced LDH release (Fig. 1). The membrane-toxic effects of the plant extracts were in the order of rosemary $>$ sage $>$ oregano $>$ echinacea.

\section{Effects of plant extracts on cell viability in Caco-2 cells}

Caco-2 cells were supplemented with or without increasing concentrations of rosemary, oregano, sage or echinacea $(5-1000 \mu \mathrm{g} / \mathrm{ml})$ for $24 \mathrm{~h}$. Following incubation, the effect of the plant extracts on cell viability was assessed using the neutral red uptake assay. Cell viability in control and carrier control samples was greater than $95 \%$ for all experiments (data not shown). On the addition of rosemary $(\geq 30 \mu \mathrm{g} / \mathrm{ml})$, cell viability was significantly reduced $(P<0.01 ;$ Fig. 2$)$. The addition of higher concentrations of sage $(\geq 120 \mu \mathrm{g} / \mathrm{ml})$ or oregano $(\geq 250 \mu \mathrm{g} / \mathrm{ml})$ significantly decreased cell viability compared with control cells $(P<0 \cdot 01)$. Echinacea was toxic only at the highest concentration tested $(P<0 \cdot 01$; Fig. 2$)$. The cytotoxic effects of the plant extracts were in the order of rosemary $>$ sage $>$ oregano $>$ echinacea. Using data obtained from the neutral red uptake assay, the $\mathrm{IC}_{50}$ value for each plant extract was determined. Rosemary had an $\mathrm{IC}_{50}$ value of $123 \mu \mathrm{g} / \mathrm{ml}$, sage had an $\mathrm{IC}_{50}$ value of $214 \mu \mathrm{g} / \mathrm{ml}$ whereas oregano had a value of $318 \mu \mathrm{g} / \mathrm{ml}$. Because the highest concentration of echinacea resulted in approximately $64 \%$ cell viability $(P<0 \cdot 01)$, the predicted $\mathrm{IC}_{50}$ value was

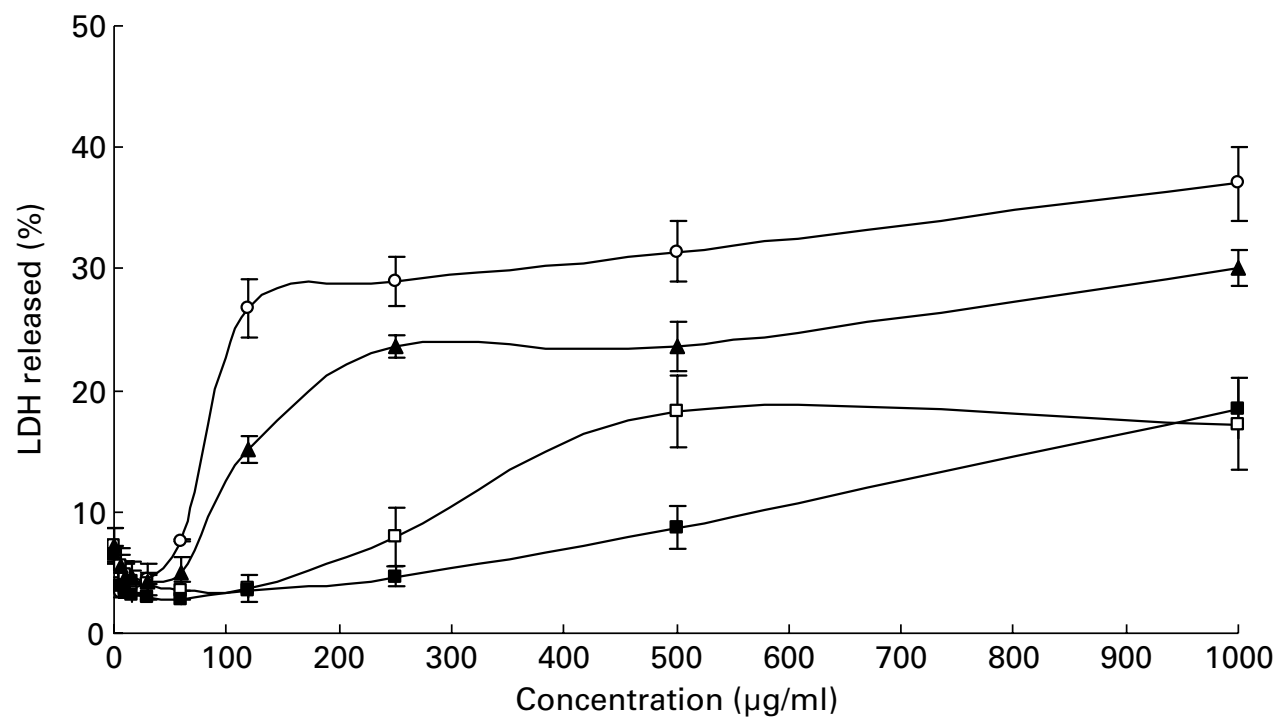

Fig. 1. Cell membrane integrity of Caco-2 cells following supplementation with or without increasing concentrations (5-1000 $\mu$ g/ml) of rosemary (-O-), oregano $(-\square-)$, sage (- $\left.\boldsymbol{\Delta}_{-}\right)$or echinacea (-口-) extracts for $24 \mathrm{~h}$. Cell membrane integrity was assessed using the lactate dehydrogenase release assay (see p. 322 ). Data are the means of four independent experiments, with standard errors represented by vertical bars. 


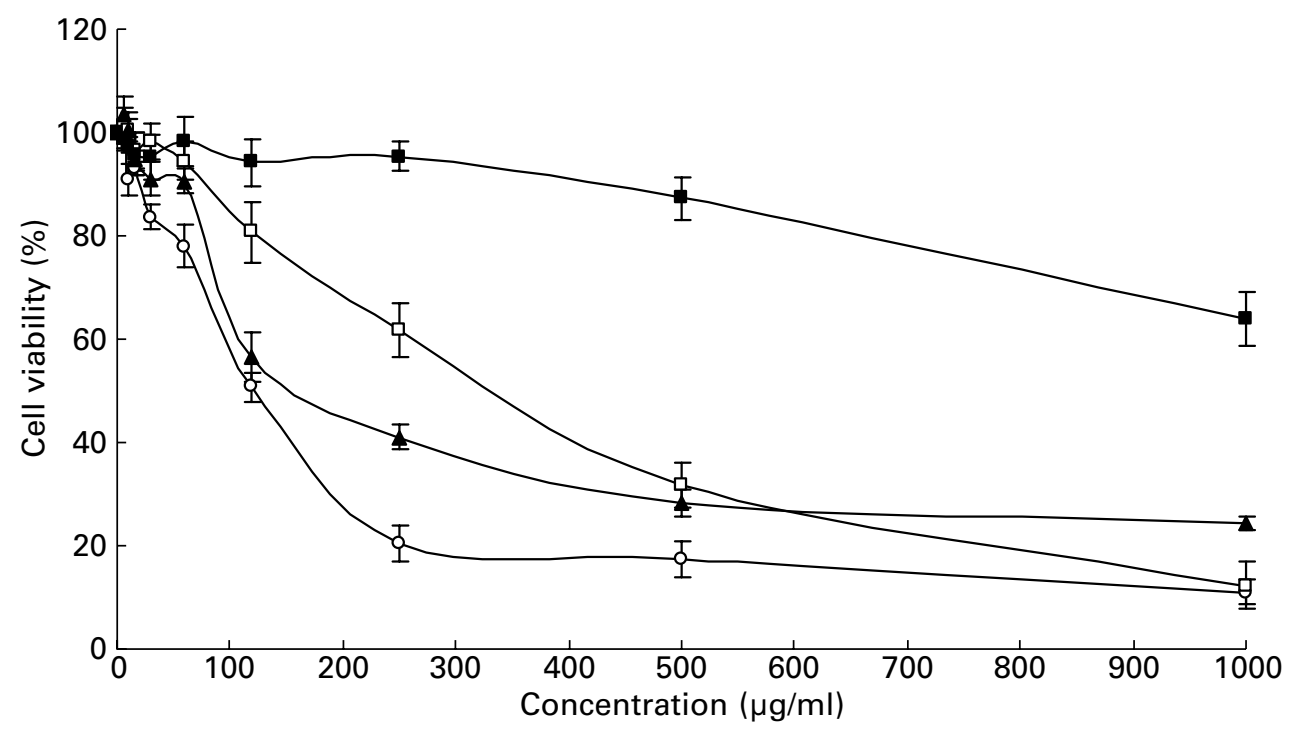

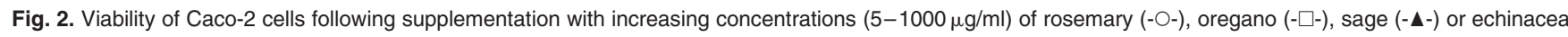
(-m-) extracts for $24 \mathrm{~h}$. Cell viability was determined using the neutral red uptake assay (see p. 322). Data are the means of four independent experiments, with standard errors represented by vertical bars.

$1421 \mu \mathrm{g} / \mathrm{ml}$. Concentrations below the $\mathrm{IC}_{50}$ value that corresponded to greater than $90 \%$ cell viability were selected for use in subsequent assays. Exposing Caco-2 cells to $\mathrm{H}_{2} \mathrm{O}_{2}$ $(50 \mu \mathrm{M}$ for $30 \mathrm{~min})$ in the absence of serum did not affect cell viability (data not shown).

\section{Effects of plant extracts on antioxidant status of Caco-2 cells}

Caco-2 cells were supplemented with or without rosemary $(15 \mu \mathrm{g} / \mathrm{ml})$, oregano $(60 \mu \mathrm{g} / \mathrm{ml})$, sage $(60 \mu \mathrm{g} / \mathrm{ml})$ or echinacea $(250 \mu \mathrm{g} / \mathrm{ml})$ for a period of $24 \mathrm{~h}$. Following incubation, GSH content, catalase activity and superoxide dismutase activity were determined. Treatment with rosemary, oregano or echinacea had no effect on cellular GSH content whereas incubation of cells with sage for $24 \mathrm{~h}$ significantly increased GSH content $(P<0 \cdot 01)$ compared with control cells (Fig. 3). There was no significant difference in catalase activity and superoxide dismutase activity between treated and non-treated cells (data not shown).

\section{Effects of plant extracts or hydrogen peroxide on DNA} integrity of Caco-2 cells

The potential of the plant extracts to induce single-strand DNA breaks was assessed using the comet assay. Caco- 2 cells were supplemented with or without rosemary $(15 \mu \mathrm{g} / \mathrm{ml})$, oregano $(60 \mu \mathrm{g} / \mathrm{ml})$, sage $(60 \mu \mathrm{g} / \mathrm{ml})$ or echinacea $(250 \mu \mathrm{g} / \mathrm{ml})$ for $24 \mathrm{~h}$. None of the four plant extracts investigated significantly

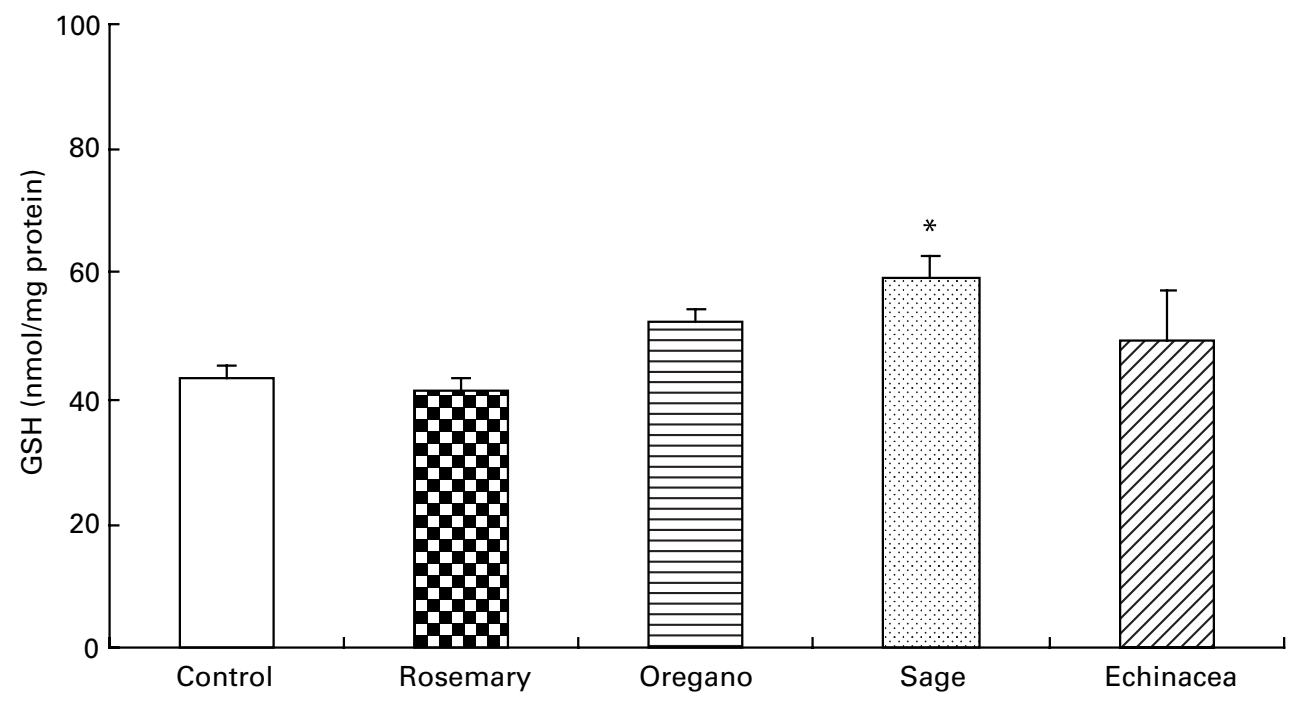

Fig. 3. GSH content of Caco-2 cells following supplementation with or without rosemary ( $15 \mu \mathrm{g} / \mathrm{ml})$, oregano $(60 \mu \mathrm{g} / \mathrm{ml})$, sage $(60 \mu \mathrm{g} / \mathrm{ml})$ or echinacea $(250 \mu \mathrm{g} / \mathrm{ml})$ extracts for $24 \mathrm{~h}$. Data are the means of four independent experiments, with standard errors represented by vertical bars. * Mean value was significantly different from that for control $(P<0.01$; one-way ANOVA followed by Dunnett's test). 
increased the formation of DNA single-strand breaks when compared with control cells (data not shown). Caco-2 cells were exposed to $50 \mu \mathrm{M}-\mathrm{H}_{2} \mathrm{O}_{2}$ for $30 \mathrm{~min}$ at $37^{\circ} \mathrm{C}$. Addition of $\mathrm{H}_{2} \mathrm{O}_{2}$ to the culture medium significantly increased DNA damage both in terms of percentage tail DNA and OTM $(P<0 \cdot 01$; Figs. 4 (A) and (B)).

\section{Effects of plant extracts on hydrogen peroxide-induced DNA damage}

Caco-2 cells were pre-incubated with or without rosemary $(15 \mu \mathrm{g} / \mathrm{ml})$, oregano $(60 \mu \mathrm{g} / \mathrm{ml})$, sage $(60 \mu \mathrm{g} / \mathrm{ml})$ or echinacea $(250 \mu \mathrm{g} / \mathrm{ml})$ extracts for $24 \mathrm{~h}$ followed by exposure to $50 \mu \mathrm{M}$ $\mathrm{H}_{2} \mathrm{O}_{2}$ for $30 \mathrm{~min}$ at $37^{\circ} \mathrm{C}$. Similar trends of genoprotection were seen when DNA damage was expressed as either percentage tail DNA or OTM (Figs. 4 (A) and (B)). Pre-treatment with rosemary or oregano significantly decreased $\mathrm{H}_{2} \mathrm{O}_{2}$ induced DNA damage $(P<0.05)$ when compared with cells treated only with $\mathrm{H}_{2} \mathrm{O}_{2}$ (Figs. 4 (A) and (B)). Supplementation with sage produced a more significant reduction in $\mathrm{H}_{2} \mathrm{O}_{2}$ induced DNA damage $(P<0 \cdot 01$; Figs. 4 (A) and (B)).

\section{Effects of plant extracts on hydrogen peroxide-induced cell injury}

Caco-2 cells were pre-incubated with or without rosemary $(15 \mu \mathrm{g} / \mathrm{ml})$, oregano $(60 \mu \mathrm{g} / \mathrm{ml})$, sage $(60 \mu \mathrm{g} / \mathrm{ml})$ or echinacea $(250 \mu \mathrm{g} / \mathrm{ml})$ extracts for $24 \mathrm{~h}$ followed by exposure to increasing concentrations of $\mathrm{H}_{2} \mathrm{O}_{2}(100-500 \mu \mathrm{M})$ for $2 \mathrm{~h}$ at $37^{\circ} \mathrm{C}$. Although treatment with $100 \mu \mathrm{M}-\mathrm{H}_{2} \mathrm{O}_{2}$ for $2 \mathrm{~h}$ reduced cell viability, the effect was not significant (Table 1). None of the plant extracts modulated this oxidant-induced reduction in cell viability. The addition of higher concentrations of $\mathrm{H}_{2} \mathrm{O}_{2}(250$ and $500 \mu \mathrm{M})$ significantly decreased $(P<0 \cdot 01)$ the viability of cells compared with control (Table 1). Sage was the only extract to significantly protect against $\mathrm{H}_{2} \mathrm{O}_{2}$-induced cytotoxicity $(P<0 \cdot 05)$. Although not significant, pre-treatment
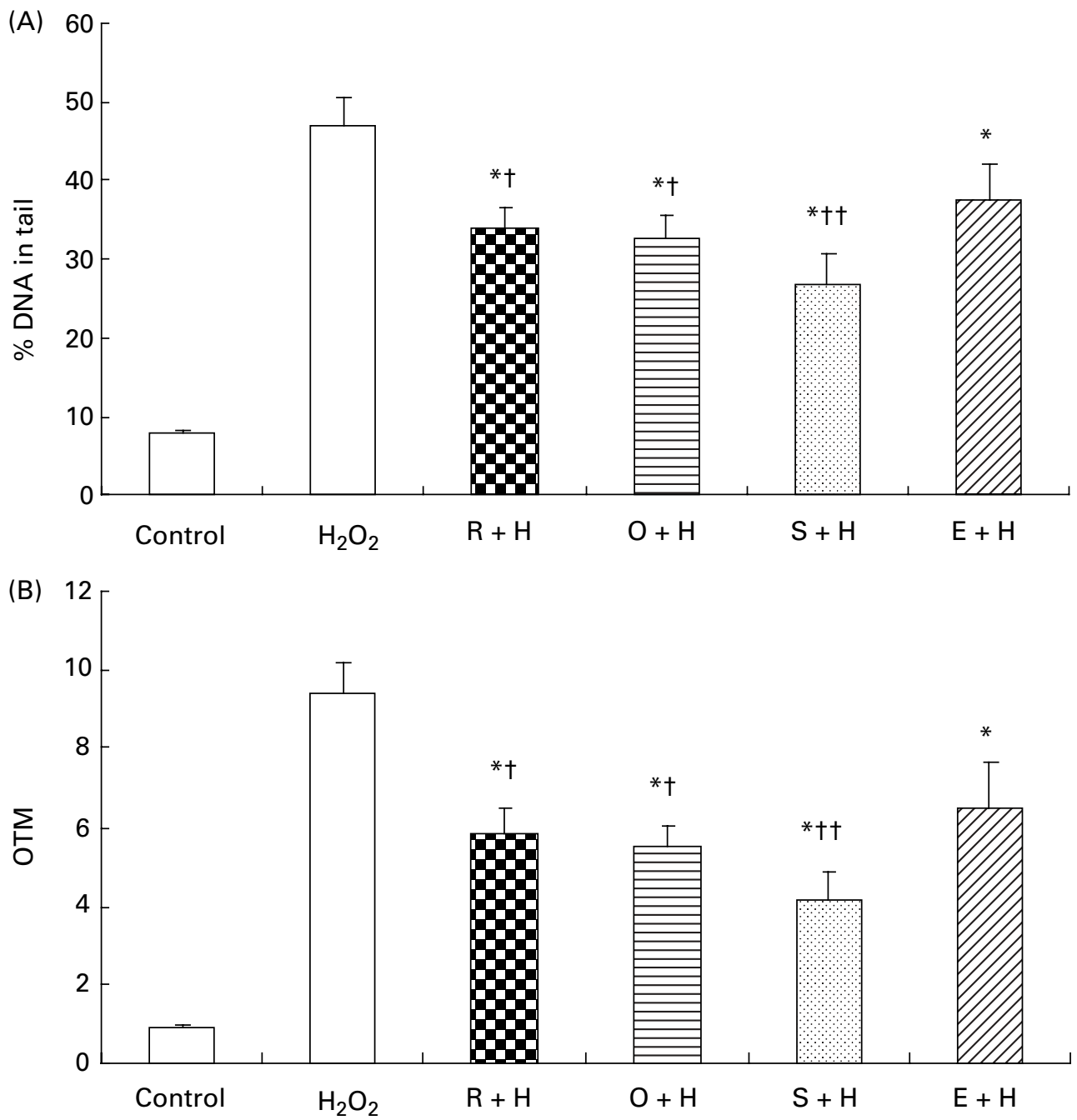

Fig. 4. DNA damage in Caco-2 cells following pre-treatment with or without extracts of rosemary (R; $15 \mu \mathrm{g} / \mathrm{ml})$, oregano $(\mathrm{O} ; 60 \mu \mathrm{g} / \mathrm{ml})$, sage $(\mathrm{S} ; 60 \mu \mathrm{g} / \mathrm{ml})$ or echinacea $\left(\mathrm{E} ; 250 \mu \mathrm{g} / \mathrm{ml}\right.$ ) for $24 \mathrm{~h}$ then exposed to $50 \mu \mathrm{M}-\mathrm{H}_{2} \mathrm{O}_{2}(\mathrm{H})$ for $30 \mathrm{~min}$ at $37^{\circ} \mathrm{C}$. DNA damage was assessed by the comet assay (see pp. $\left.322-323\right)$. (A) Percentage tail DNA; (B) olive tail moment (OTM), which represents the product of the tail length and the percentage tail DNA. Data are the means of four independent experiments, with standard errors represented by vertical bars. Statistical analysis was by one-way ANOVA followed by Dunnett's test. * Mean value was significantly different from that for control $(P<0.01)$. Mean value was significantly different from that for $\mathrm{H}_{2} \mathrm{O}_{2}$-treated cells: $\dagger P<0.05$, $\dagger+P<0.01$. 
Table 1. Viability of Caco-2 cells after pre-treatment with or without plant extracts for $24 \mathrm{~h}$ followed by exposure to hydrogen peroxideł

(Mean values with their standard errors; three individual experiments)

\begin{tabular}{|c|c|c|c|c|c|c|}
\hline \multirow[b]{3}{*}{ Treatments... } & \multicolumn{6}{|c|}{ Cell viability $(\%) \S$} \\
\hline & \multicolumn{2}{|c|}{$100 \mu \mathrm{m}$} & \multicolumn{2}{|c|}{$250 \mu \mathrm{m}$} & \multicolumn{2}{|c|}{$500 \mu \mathrm{m}$} \\
\hline & Mean & SEM & Mean & SEM & Mean & SEM \\
\hline $\mathrm{H}_{2} \mathrm{O}_{2}$ & $69 \cdot 6$ & $6 \cdot 0$ & $27 \cdot 9^{\star}$ & $8 \cdot 4$ & $18 \cdot 9^{*}$ & $9 \cdot 9$ \\
\hline Rosemary $+\mathrm{H}_{2} \mathrm{O}_{2}$ & $70 \cdot 6$ & $4 \cdot 7$ & $29 \cdot 4^{*}$ & 3.4 & $35 \cdot 8^{*}$ & $7 \cdot 1$ \\
\hline Oregano $+\mathrm{H}_{2} \mathrm{O}_{2}$ & $62 \cdot 3$ & 0.7 & $28 \cdot 0^{*}$ & $4 \cdot 1$ & $23 \cdot 5^{\star}$ & 1.6 \\
\hline Sage $+\mathrm{H}_{2} \mathrm{O}_{2}$ & $70 \cdot 9$ & $6 \cdot 3$ & $55 \cdot 5^{\star} \dagger$ & $4 \cdot 6$ & $49 \cdot 6^{*} \dagger$ & $3 \cdot 6$ \\
\hline Echinacea $+\mathrm{H}_{2} \mathrm{O}_{2}$ & $80 \cdot 3$ & $14 \cdot 4$ & $46 \cdot 3^{*}$ & $11 \cdot 0$ & $35 \cdot 4^{*}$ & $5 \cdot 9$ \\
\hline
\end{tabular}

*Mean value was significantly different from that for control $(P<0.01$; one-way ANOVA, followed by Dunnett's test).

† Mean value was significantly different from that for $\mathrm{H}_{2} \mathrm{O}_{2}$-treated cells $(P<0.05$; one-way ANOVA, followed by Dunnett's test).

¥Caco-2 cells were grown in the presence or absence of rosemary $(15 \mu \mathrm{g} / \mathrm{ml})$, oregano $(60 \mu \mathrm{g} / \mathrm{ml})$, sage $(60 \mu \mathrm{g} / \mathrm{ml})$ or echinacea $(250 \mu \mathrm{g} / \mathrm{ml})$ extracts for $24 \mathrm{~h}$ followed by exposure to increasing concentrations of $\mathrm{H}_{2} \mathrm{O}_{2}$ for $2 \mathrm{~h}$ at $37^{\circ} \mathrm{C}$.

$\S$ Determined using the neutral red uptake assay (see p. 322). Results are expressed as a percentage of the control (100\%).

with rosemary and echinacea did show a certain degree of cytoprotection against $\mathrm{H}_{2} \mathrm{O}_{2}$ (Table 1).

\section{Discussion}

Fruits, vegetables and herbs contain a wide variety of phytochemicals that possess bioactive properties which may help protect cellular systems from oxidative damage (Liu, 2003). In the present study, the biological effects of four plant extracts, namely rosemary, oregano, sage and echinacea were investigated. While there has been interest in the antioxidant activity of rosemary, oregano and sage and immunomodulatory effects of echinacea, limited information exists on their cytoprotective and genoprotective effects on cells in culture.

Many constituents in rosemary, oregano and sage such as phenolic acids (including rosmarinic and caffeic), phenolic compounds and flavonoids have been reported to exhibit a broad range of biological activities in vitro and in vivo including antioxidant, anti-inflammatory, anti-microbial, antimutagenic, and anti-tumour effects (Aruoma et al. 1996; Miura et al. 2002; Petersen \& Simmonds, 2003; Chorianopoulos et al. 2004; Osakabe et al. 2004; Aydin et al. 2005; Capecka et al. 2005). Echinacea purpurea has been reported to act as an anti-inflammatory agent and an immunostimulant (Craig, 1999; Linde et al. 2006) and is widely consumed for the prevention and treatment of upper respiratory tract infections (Barrett et al. 1999, 2002; Hwang et al. 2004; Linde et al. 2006). However, the exact mechanism(s) of action remain unclear and available evidence from clinical trials on the effectiveness of echinacea has been considered inconsistent (Barrett et al. 2002; Linde et al. 2006).

To establish the effects of the four plant extracts on membrane integrity in Caco-2 cells, leakage of the membranebound enzyme LDH was determined. The order of 'membrane potency' among the four plant extracts correlated well with our cytotoxicity data and $\mathrm{IC}_{50}$ values. Supplementation with increasing concentrations of rosemary for $24 \mathrm{~h}$ caused cytotoxicity at concentrations $\geq 30 \mu \mathrm{g} / \mathrm{ml}$ in Caco- 2 cells. Slameňová et al. (2002) determined the viability of Chinese hamster lung fibroblast V79 cells following supplementation with various concentrations of rosemary for $24 \mathrm{~h}$. Cytotoxicity was reported at concentrations $\geq 15 \mu \mathrm{g} / \mathrm{ml}$. In the present study both oregano and sage, also members of the Lamiaceae family, affected cell viability in a dose-dependent manner similar to that of rosemary. However, rosemary, having the lowest $\mathrm{IC}_{50}$ value of $123 \mu \mathrm{g} / \mathrm{ml}$, was most toxic of the extracts to Caco-2 cells and echinacea was the least toxic with a predicted $\mathrm{IC}_{50}$ of $1421 \mu \mathrm{g} / \mathrm{ml}$. Carpenter et al. (2006) who investigated the effects of various plant extracts on the viability of U937 cells reported that echinacea was the least toxic plant extract of those tested, with the highest $\mathrm{IC}_{50}$ value of $9400 \mu \mathrm{g} / \mathrm{ml}$.

There are many ways to express DNA damage as assessed by the comet assay, and the two most common endpoints reported are OTM and percentage tail DNA. According to Møller (2006), in order to provide feasible comparisons of DNA damage between studies, it is important that common reference endpoints are agreed upon and that researchers provide the opportunity for comparison. Therefore we expressed DNA damage in terms of OTM and percentage tail DNA (Fig. 4). Similar trends were seen when DNA damage was expressed as either of these two endpoints.

It is known that DNA strand breaks occur when cells are exposed to $\mathrm{H}_{2} \mathrm{O}_{2}$ (Meneghini \& Martins, 1993; Kruszewski et al. 1994). In the present study, we exposed Caco-2 cells to $50 \mu \mathrm{M}-\mathrm{H}_{2} \mathrm{O}_{2}$ for $30 \mathrm{~min}$ at $37^{\circ} \mathrm{C}$ which resulted in significant DNA single-strand-break formation (Figs. 4 (A) and (B)). These findings are in agreement with previous work carried out in our laboratory (Aherne \& O'Brien, 1999, 2000). The plant extracts themselves did not induce DNA damage at the concentrations and exposure times tested. Even though oregano extract had less than half the total phenolic content of rosemary or sage, we found that sage, oregano and rosemary, in that order, protected against $\mathrm{H}_{2} \mathrm{O}_{2}$-induced DNA damage in Caco- 2 cells. Research has shown that the antioxidant effectiveness of rosemary, oregano and sage extracts in vitro is due to their ability to act as reducing agents and free radical scavengers, as quenchers of singlet $\mathrm{O}_{2}$ formation and to complex with pro-oxidant metal ions (Miura et al. 2002; Dorman et al. 2003; Amarowicz et al. 2004; Moreno et al. 2006; Slameňová et al. 2002). Thus the genoprotective effects of the plant extracts could be due, in part, to their free radical-scavenging efficiency and reducing power, as a result of their phenolic and/or non-phenolic constituents.

Sage was the only plant extract to exert a protective effect against $\mathrm{H}_{2} \mathrm{O}_{2}$-induced cytotoxicity. Therefore, sage may afford this protection against $\mathrm{H}_{2} \mathrm{O}_{2}$-induced cell injury by mechanisms other than those already mentioned. Chiou \& Tzeng (2000) reported that the resistance of K300 cells to menadione-induced cytotoxicity may be due, in part, to the elevated concentrations of GSH in these cells. Therefore, it is possible that sage protected against $\mathrm{H}_{2} \mathrm{O}_{2}$-induced cytotoxicity by improving the antioxidant status of Caco- 2 cells. The present results show that rosemary, oregano and echinacea had no effect on the antioxidant status of Caco-2 cells or on $\mathrm{H}_{2} \mathrm{O}_{2}$ induced cytotoxicity. However, supplementation with sage enhanced cellular GSH content and protected cells against $\mathrm{H}_{2} \mathrm{O}_{2}$-induced cytotoxicity. This mechanism could also explain why sage afforded the greatest protection against $\mathrm{H}_{2} \mathrm{O}_{2}$-induced DNA damage. 
Prevention is a more effective strategy than treatment of chronic diseases. Incorporation of herbs into everyday meals may be beneficial, as a diet in which culinary herbs are used generously provides a variety of active phytochemicals that could promote good health by protecting tissues against $\mathrm{O}_{2}$ induced damage, and preventing the onset of chronic diseases (Craig, 1999). Health benefits resulting from the use of natural plant products rich in bioactive substances has promoted growing interest from pharmaceutical, food and cosmetic industries (Capecka et al. 2005). The findings of the present study suggest that the proper use of herb products is safe and may provide some beneficial effects; however, our toxicity data justify concerns regarding the consumption of high doses that are unsafe and possibly harmful to human health.

\section{Acknowledgements}

The present study was funded under the National Development Plan (2000-6), through the Food Institutional Research Measure, administered by the Irish Department of Agriculture and Food.

\section{References}

Aherne SA \& O'Brien NM (1999) Protection by the flavonoids, myricetin, quercetin and rutin, against hydrogen peroxide-induced DNA damage in Caco-2 and HepG2 cells. Nutr Cancer 34, 160-166.

Aherne SA \& O'Brien NM (2000) Lack of effect of the flavonoids, myricetin, quercetin and rutin, on repair of hydrogen peroxideinduced DNA single strand breaks in Caco-2, HepG2 and V79 cells. Nutr Cancer 38, 106-115.

Amarowicz R, Pegg RB, Rahimi-Moghaddam P, Barl B \& Weil JA (2004) Free radical scavenging capacity and antioxidant activity of selected plant species from the Canadian prairies. Food Chem 84, 551-562.

Aruoma OI, Spencer JP, Rossi R, Aeschbach R, Khan A, Mahmood N, Munoz A, Murcia A, Butler J \& Halliwell B (1996) An evaluation of the antioxidant and antiviral action of extracts of rosemary and Provencal herbs. Food Chem Toxicol 34, 449-456.

Aydin S, Basaran AA \& Basaran N (2005) Modulating effects of thyme and its major ingredients on oxidative DNA damage in human lymphocytes. J Agric Food Chem 53, 1299-1305.

Babbs CF (1992) Oxygen radicals in ulcerative colitis. Free Radic Biol Med 13, 169-181.

Babich H \& Borenfreund E (1992) Neutral red assay for toxicology in vitro. In In vitro Methods of Toxicology, pp. 235-251 [RR Watson, editor]. Boca Raton, FL: CRC Press.

Barrett B, Vohmann M \& Calabrese C (1999) Echinacea for upper respiratory infection. J Fam Pract 48, 628-635.

Barrett BP, Brown RL, Locken K, Maberry R, Bobula JA \& D'Alessio D (2002) Treatment of the common cold with unrefined Echinacea. A randomised, double-blind, placebo-controlled trial. Ann Intern Med 137, 939-946.

Baudhuin P, Beaufay H, Rahman-Li Y, Sellinger OZ, Wattiaux R, Jacques $P$ \& deDuve $C$ (1964) Intracellular distribution of monoamine oxidase, aspartate aminotransferase, alanine aminotransferase, Damino acid oxidase and catalase in rat liver. Biochem J 92, 179-184.

Bozin B, Mimica-Dukic N, Simin N \& Anackov G (2006) Characterization of the volatile composition of essential oils of some lamiaceae spices and the antimicrobial and antioxidant activities of the entire oils. J Agric Food Chem 54, 1822-1828.

Capecka E, Mareczek A \& Leja M (2005) Antioxidant activity of fresh and dry herbs of some Lamiaceae species. Food Chem 93, 223-226.
Carpenter R, O'Callaghan YC, O'Grady M, Kerry JP \& O'Brien NM (2006) Modulatory effects of resveratrol, citroflavan-3-ol and plant-derived extracts on oxidative stress in U937 cells. J Med Food 9, 187-195.

Chanwitheesuk A, Teerawutgulrag A \& Rakariyatham N (2005) Screening of antioxidant activity and antioxidant compounds of some edible plants of Thailand. Food Chem 92, 491-497.

Chiou TJ \& Tzeng WF (2000) The roles of glutathione and antioxidant enzymes in menadione-induced oxidative stress. Toxicol 154, 75-84.

Chorianopoulos N, Kalpoutzakis E, Aligiannis N, Mitaku S, Nychas GJ \& Haroutounian SA (2004) Essential oils of Satureja, Origanum, and Thymus species: chemical composition and antibacterial activities against foodborne pathogens. J Agric Food Chem 52, 8261-8267.

Craig WJ (1999) Health-promoting properties of common herbs. Am J Clin Nutr 70, 491S-499S.

Dorman HJ, Peltoketo A, Hiltunen R \& Tikkanen MJ (2003) Characterisation of the antioxidant properties of de-odourised aqueous extracts from selected Lamiaceae herbs. Food Chemistry 83, 255-262.

Halliwell B \& Gutteridge JMC (1999) Free Radicals in Biology and Medicine, 3rd ed., New York: Oxford University Press.

Hissin PJ \& Hilf R (1976) A fluorometric method for determination of oxidized and reduced glutathione in tissues. Anal Biochem 74, 214-226.

Hwang SA, Dasgupta A \& Actor JK (2004) Cytokine production by non-adherent mouse splenocyte cultures to Echinacea extracts. Clin Chim Acta 343, 161-166.

Kris-Etherton PM, Hecker KD, Bonanome A, Coval SM, Binkoski AE, Hilpert KF, Griel AE \& Etherton TD (2002) Bioactive compounds in foods: their role in the prevention of cardiovascular disease and cancer. Am J Med 113, 71S-88S.

Kruszewski M, Green MHL, Lowe JE \& Szumiel I (1994) DNA strand breakage, cytotoxicity and mutagenicity of hydrogen peroxide treatment at $4^{\circ} \mathrm{C}$ and $37^{\circ} \mathrm{C}$ in L5178Y sublines. Mutat Res 308, 233-241.

Linde K, Barrett B, Wolkart K, Bauer R \& Melchart D (2006) Echinacea for preventing and treating the common cold. Cochrane Database Syst Rev, Art No CD000530, issue 1, 1-9.

Liu RH (2003) Health benefits of fruit and vegetables are from additive and synergistic combinations of phytochemicals. Am J Clin Nutr 78, 517S-520S.

McCord JM \& Fridovich I (1969) Superoxide dismutase. An enzyme function for erythrocuprein (hemocuprein). J Biol Chem 244, 6049-6055.

Meneghini R \& Martins EL (1993) Hydrogen peroxide and DNA damage. In DNA and Free Radicals, pp. 83-93 [B Halliwell and OI Aruoma, editors]. New York: Ellis Horwood.

Mielnik M, Aaby K \& Skrede G (2003) Commercial antioxidants control lipid oxidation in mechanically deboned turkey meat. Meat Sci 65, 1147-1155.

Miura K, Kikuzaki H \& Nakatani N (2002) Antioxidant activity of chemical components from sage (Salvia officinalis L.) and thyme (Thymus vulgaris L.) measured by the oil stability index method. J Agric Food Chem 50, 1845-1851.

Møller P (2006) Assessment of reference values for DNA damage detected by the comet assay in human blood cell DNA. Mutat Res 612, 84-104.

Moreno S, Scheyer T, Romano CS \& Vojnov AA (2006) Antioxidant and antimicrobial activities of rosemary extracts linked to their polyphenol composition. Free Radic Res 40, 223-231.

Osakabe N, Yasuda A, Natsume M \& Yoshikawa T (2004) Rosmarinic acid inhibits epidermal inflammatory responses: anticarcinogenic effect of Perilla frutescens extract in the murine twostage skin model. Carcinogenesis 25, 549-557.

Parthasarathy S, Santanam N, Ramachandran S \& Meilhac O (1999) Oxidants and antioxidants in atherogenesis. An appraisal. J Lipid Res 40, 2143-2157. 
Petersen M \& Simmonds MS (2003) Rosmarinic acid. Phytochem 62, $121-125$.

Singleton V \& Rossi J (1965) Colorimetry of total phenolics with phosphomolybdic-phosphotungstic acid reagents. Am J Enol Vitic 16, 144-158.

Slameňová D, Kuboskova K, Horvathova E \& Robichova S (2002) Rosemary-stimulated reduction of DNA strand breaks and FPG-sensitive sites in mammalian cells treated with $\mathrm{H}_{2} \mathrm{O}_{2}$ or visible light-excited methylene blue. Cancer Lett 177, $145-153$.

Smith PK, Krohn RI, Hermanson GT, et al. (1985) Measurement of protein using bicinchoninic acid. Anal Biochem 150, 76-85.
Sohal RS, Mockett RJ \& Orr WC (2002) Mechanisms of aging: an appraisal of the oxidative stress hypothesis. Free Radic Biol Med 33, $575-586$.

Tice RR, Andrews PW, Hirai O \& Singh NP (1990) The single cell gel (SCG) assay: an electrophoretic technique for the detection of DNA damage in individual cells. In Biological and Reactive Intermediates IV, pp. 157-164 [CM Witmer, editor]. New York: Plenum Press.

Zainol MK, Abd-Hamid A, Yusof S \& Muse R (2003) Antioxidative activity and total phenolic compounds of leaf, root and petiole of four accessions of Centella asiatica (L.) Urban. Food Chem 81, $575-581$. 